\title{
Modernisme: ten diepste ons identiteit?
}

\author{
H.J. Hendriks \\ Dept. Praktiese Teologie en Missiologie \\ Universiteit van Stellenbosch \\ STELLENBOSCH
}

\begin{abstract}
Modernism: our true identity?

The basic presupposition of this article is that South Africans of European descent are now discovering how modernist their identity really is. The political changes in our country and our concomitant disillusionment strongly drive this realisation home. The way in which the church loses and probably will contimue losing members, is a symptom of the consequences of a modernist identity. To promote insight in the modernist identity, this article discusses the historical course and philosophical choices which gave rise to a modernist spirit. Throughout this article the way in which this spirit destructively and secularistically affects the community is pointed out. The challenges faced by the church are mentioned briefly.
\end{abstract}

\section{Inleiding}

April 1994 was in meer as een opsig 'n waterskeiding: meer as 'n fratsgolf het die Suid-Afrikaanse samelewing getref. Die probleemstelling wat in hierdie artikel ondersoek word, is genig op die bedieningspraktyk. Mense se basiese lojaliteite teenoor kerk- en kultuurorganisasies taan, onbetrokkenheid is aan die orde van die dag - 'n probleem wat deur empiriese navorsing bevestig word. Die gevestigde denominasies in Suid-Afrika is besig om op ' $n$ dramatiese wyse blanke en brum lidmate te verloor (Hendriks, 1995:35-58; 1996:138-145). Hierdie proses kan die begin wees van dieselfde proses wat hom kort na die Tweede Wêreldoorlog in Europa gemanifesteer het (Brierley, 1989:39-80; Dekker, 1992) en sedert die sestigerjare in die VSA ingetree het (Mead, 1994:812; Finke \& Stark, 1992). Die huidige bedieningspraktyk raak die moderne mens hoe langer hoe meer nie meer aan nie

Die kerk bevind hom in 'n situasie waar koersaanpassing nodig is. In hierdie artikel word beskryf hoe gewone mense in die modernistiese sisteem ingetrek is en hoe dié proses die kerk se identiteit misvorm. Ons noem onsself gereformeerdes, maar die Modernisme is waarskynlik 'n beter tipering van ons alledaagse identiteit en lewenstyl. Naas die inleidende kursoriese oorsig oor die geskiedenis tot en met die tyd van die Verligting (vgl. Brueggemann 1993), konsentreer hierdie artikel daarop om die denkvertrekpunte van die Modernisme 
te verduidelik en die inıplikasies daarvan op ons samelewing en op onsself aan te toon.

Die skrywer werk met twee hipoteses. In 'n veranderende konteks help dit nie om verandering in ' $n$ gemeente en gemeenskap te probeer bewerkstelling deur bloot die programme en prosesse van 'n gemeente te vcrander nie. Konstruktiewe en wesenlike verandering vind alleen op die vlak van identiteit plaas (Mead, 1991:69-71; Carroll, Dudiey \& McKinney, 1986:11-15, 21-47; Tucker, 1990: 66-85; Coalter, Mulder \& Weeks, 1992:261-287). Die artikel gaan nie 'n beskrywing van die postmodernisme situasie gee nie maar slegs daama verwys. Ook word nie gepoog om gedetaileerde implikasies van die paradigmaverskuiwing vir die bedieningspraktyk uit te spel nie. Albei onderwerpe sou selfstandige artikels in eie reg wees. Die hipotese waarmee die skrywer egter werk, is dat daar 'n meer fundamentele eerste stap is waarby stilgestaan moet word: ons moet die DNA-struktuur ${ }^{1}$ van ons modernistiesgeorienteerde identiteit verstaan. Eers as ons, figuurlik gesproke, die "sonde" in onsself erken, kan ons tot belydenis en bekering kom. Eers daarna maak dit sin om aan die ander sake aandag te gee. Insig in die kem van 'n probleem gaan verdere wetenskaplike besinning voorar. Hierop probeer die artikel fokus.

\section{Die Apostolicse era (AD 30-313)}

Die kerk het na Jesus Christus se lewe op aarde bepaalde kenmerke vertoon en sy verhouding tot die wêreld rondom hom was baie anders as vandag Die aard van die kerk van Christus kan soos volg getipeer word (Bosch, 1991:190-192; Mead, $1991: 9$ e.v.):

- Die kerk se identiteit is onder andere gevorm op grond van geloof in Jesus Christus as die Seun van God, die Messias, en op grond van gedeeltes soos die Bergrede (Matteus 5-7).

- Mense wat lidmate van die kerk geword het, het dit op grond van die ervaring van 'n wedergeboorte gedoen. Dit was 'n stap wat hulle aan vervolging en diskriminasie blootgestel het.

- Die kerk is deur die gemeenskap as ' $n$ sekte beskou; dit het anders as die wêreld geleef en is vervolg. Die grens tussen kerk en wêreld was dus baie duidelik.

1 In die DNA-struktuur van 'n sel se gene word die volledigc bloudruk of identiteit van die lewende organisme gevind 
- Lidmate was getuies en evangelisasie het natuurlikerwys as 'n lewenswyse plaasgevind volgens die gawes wat elke lidmaat ontvang het.

- Gedurende die eerste drie eeue na Christus was die kerk se bestaan gekenmerk deur klein geloofsgemeenskappies en huiskerke (Banks \& Banks, 1986; Meeks, 1983).

\section{Die era van die Christendom (AD 313 - 27 April 1994)}

Teen die vierde eeu ontwikkel daar egter 'n nuwe paradigma (Mead, 1991:1329)2 ${ }^{2}$. Die Romeinse keiser, Konstantyn, aanvaar in 313 n.C. die Christelike geloof en die Christendom word weldra die staatsgodsdiens van die Ryk. Algaande begin die kerk ander kenmerke vertoon:

- Mense word lidmate omdat dit baie voordele inhou om aan die staatskerk te behoort; dit is eerder 'n risiko om nie aan die kerk te behoort nie.

- Die verhouding tussen die kerk en staat is voordelig vir albei partye en die grense tussen kerk ell die gemeenskap, asook die staat, disintegreer. Christene is nie meer "anders as" hulle omgewing nie.

- Die kerk se grense ontwikkel geografies en val saam met administratiewe gemeenskapsgrense. Gemeentes ontwikkel geografies, lidmatetalle brei uit en kerkgeboue word opgerig. 'n Uitgebreide kerklike hiërargie ontwikkel.

- Soos wat die staat sy grense uitbrei en later kolonies in ander wêrelddele stig, word die staat vergesel van die kerk met sendelinge wat die staat se godsdiens en beskawing aldaar moet gaan vestig. Die staat/kerk vervolg vals godsdienste, dwaalleraars en sektes.

- Lidmate word toenemend leke, gawes ontwikkel nie

\section{Die Verligting3}

Die periode bekend as die Verligting begin in die sewentiende eeu. Die geskiedenis demonstreer nou dramaties hoe magtig kennis is. Ongemaklikheid met die ou bedeling neem toe en onsekerheid is aan die orde van die dag. Vier manne lui, by wyse van voorbeeld, die doodsklokke van die ou bedeling:

2 'n Paradigma is 'n algenven aanvaarde stel waardes en oortuigings waarbinne mense dink en redeneer As algemoen aanvaarde vernsingsraamwerk funksioneer dit, behalwe in knsisse, onbewustelık

3 Dic anderstalige terme is Enlightenment, Aufklanung en Renaissance 
- Copernicus (1473-1543) laat almal regop sit toe hy beweer dat die aarde in 24 uur om sy as en in 365 dae om die son draai. Hierdie bewering het mense laat uitroep watter sekerhede dan nog hierna kan vasstaan.

- Columbus (1446?-1506) lui die ontdekking van 'n nuwe wêreld in en die aarde word getipeer as rond. Nuwe beskawings en nuwe produkte, nuwe rykdomme wink vir Europa en die groot stormloop om die aarde begin.

- Caxton (1422-1492) is die grondlegger van die boekdrukkuns in Brittanje. Die wêreld begin lees. Die Bybel word in die verskillende tale van Europa vertaal en gepubliseer; kennis en inligting versprei. Skeptisisme in ou en gevestigde idees steek oral kop uit. Onkunde en bygeloof begin verdwyn.

- Calvyn (1509-1564) en die Reformatore stel die magtige Roomse Kerk skaakmat. Die pous se gesag as stadshouer van God kwyn. Die Corpus Christianum (die groot "Christelike" magsblok) se eenheid wankel want elke land bepaal sy eie godsdiens en kry sy eie (nog Christelike) kerk om hom te ondersteun.

\section{Die rol van die Protestantisme}

Die Reformasie het die Rooms-Katolieke Kerk se mag as eenheidskerk in die Weste gebreek (Bosch, 1991:263). Let op: die mag het algaande begin verskuif en die instrumente waarmee die mens mag kan beheer en manipuleer, het begin verander. Martin Luther (1483-1546) ontdek via Augustinus weer vir Paulus: Romeine 1:16 is die sleutelteks van dié tyd. Die regverdigmaking deur die geloof alleen is die sleutelkonsep wat die Reformasie-beweging dra: dit is ' $n$ individuele besluit voor God. Die Protestantisme beywer sig vir godsdiensvryheid. Godsdiensoorloë woed in baie lande. By die Vrede van Westphalia (1648) word as beginsel aanvaar: cuius regio elus religio - 'n beginsel wat beteken dat elke gebied die godsdiens van sy regeerder kan volg (die kerk-staatverhouding betree sy laaste fase). Die sogenaamde Protestant virus lei tot die verlies van kerkeenheid. Diversiteit en pluralisme is simptome hiervan en het algaande toegeneem.

\section{Descartes se cogito ergo sum}

Wie die paradigmaverskuiwing wil verstaan, sal die meeste antwoorde in die filosofie vind. Die Fransman, Descartes (1596-1650), algemeen aanvaar as die grondlegger van die Verligting (Bosch, 1991:264), gee 'n mens werklik insae in

4 Vergelyk in dié verband Pierre Babin se bock The new era in religious communication (1991). Elke paradigma het sy eie en unicke kommunikasieuyse wat bemeester mot wond 
die waterskeidingstyd van die sewentiende eeu. Die tagtigjarige (godsdienstige) oorlog het in Wes-Europa gewoed. Daar was in baie kringe wantroue in die kerk en kerklike leiding as gevolg van die rol wat die kerk gespeel het om ou ordes te handhaaf asook oor hulle indirekte betrokkenheid in die oorloë. In hierdie klimaat van onsekerheid, formuleer Descartes sy beroemde spreuk: cogito ergo sum (ek dink, daarom is ek). Skeptisisme is die geboortemerk van die Modernisme. Descartes sê daar is net twee dinge waarvan hy seker kan wees: homself en die betroubaarheid van die rede en logika. Hy skryf 'n boek oor die reëls van die logika wat die grondslag van die opbloei van die wetenskap vorm: die resultate van die wetenskap is betroubaar, sy stellings bewysbaar, seker.

\section{Die Verligting se denkstruktuur en die implikasies daarvan}

Die Westerse kultuur het ingrypend verander onder invloed van die Verligting en die proses van sekularisasie. 5 Om die uitwerking van Descartes se spreuk en die Modernisme se DNA-struktuur op die gees van die mens, op sy denkparadigma en sy verhoudinge egter na behore te verstaan, gaan ons in navolging van Bosch (1991:262-273, 349-362) kyk na die teoretiese vertrekpunte van die denkparadigma en na die implikasies wat dit op die lang termyn op mens en maatskappy gehad het.

\subsection{Individualisme}

Descartes se spreuk is tiperend van die twee bene waarop die Modernisme staan. Die een been is die "ek". Die vertrekpunt van hierdie denke is die individu (individualisme), die mens (humanisme), die self (subjektivisme). Die mens het algaande met behulp van die wetenskap 'n mate van beheer oor sy wêreld gekry. 'n Gees van optimisme het posgevat en daar is geglo dat die mens in staat is om 'n utopie op aarde te ontwikkel. Die ontwikkelende, optimistiese mens het nie meer sekerheid en antwoorde by God gaan soek nie. Hy/sy het besluit om dit self te vind. Dit lei natuurlikerwys tot 'n nuwe politieke bedeling of paradigma. Daar is altyd "van bo" gedink - vanaf God en sy gesante (pouse, konings, adellikes): hulle het mag gehad en alles beheer. Die regeringsvorms was dus hièrargies met monargiee of vorste aan bewind. Met die Verligting swaai dit om. Die volk monster hulle mag (in politieke partye) en verwerp algaande die ou strukture. Die demokrasie kry in Europa gestalte

Op die lang termyn het hierdie gees en ingesteldheid alles om die mens laat draas. Gewoonlik word die tipiese Amerikaner as voorbeeld voorgehou (vgl. Borgmann, 1992). Die mens is ' $n$ absolute individualis en selfs God en godsdiens word gebruik om die mens se ware potensiaal te bereik, om bo uit te kom (sukses) en

5 Sekularisasie verwys na 'n proses waarin daar algaande al hoe minder met God en Christelike waardes rekening gehou word 
om 'n wenner te wees. Die self word God. Jy moet tegelykertyd mooi, goed, sterk, suksesvol, ryk, ensovoorts wees. Die ganse advertensiewese vertel hoe jy so kan word of wat jy moet koop om so te wees. Jou politieke party moet natuurlik vir jou aan die bewind hou en sorg dat jy nog ryker word. Die Amerikaans-oorheersde Suid-Afrikaanse media (televisie, films, musiek) het hierdie gees in elke huis ingedra. Ons identiteit word hierdeur wesenlik beinvloed; dit breinspoel ons.

\subsection{Rasionalisme}

Descartes se "ek dink" verwys ook na die rede, die logika. Aan die rasionalisme word daar in die volgende eeue ongelooflike waarde geheg omdat die opbloei in die wetenskap en tegnologie, die ontwikkeling wat op sovele terreine plaasgevind het, daardeur in die hand gewerk is. Die twee bene van die Modernisme, die individualisme en rasionalisme, het gelei tot wat vandag bekend staan as sekularisasie6.

Die selfvertroue van die individualistiese mens berus op sy beheer van die rede en logika soos wat dit in die natuurwetenskappe gegeld het - 'n uitgangspunt wat op alle vorme van kennis toegepas is. Ten einde 'n tuiste aan die destydse universiteite te kry, moes die teologie uiteraard volgens hierdie spelreêls probeer speel. Geloof is nie op dieselfde vlak as die rede gereken nie. Immers, oor die rede het die mens beheer gehad, geloof was "te subjektief" en nie wetenskaplik kontroleerbaar nie. Die maatskappy het binne hierdie denkparadigma sy keuses in terme van sy logika geneem en nie in terme van geloof nie. Dit is belangrik om te verstaan dat die gereformeerde leer in hierdie denkklimaat sy oorsprong het. Die intellektualistiese aard daarvan, die klem op lering het hier sy oorsprong. Ons moet die hedendaagse sug na ervaring as 'n reaksie hierop sien.

Hoewel dit vir die teologie ongekende vooruitgang beteken het, was hierdie ontwikkeling nie sonder 'n negatiewe uitwerking nie. Ons begin dit nou eers verstaan. Rasionaliteit het die geneigdheid om die waan te skep dat jy daarmee alles kan verstaan, beheer en manipuleer. Dit gee jou soveel mag dat jy soos 'n god kan voel. Dit maak uiteindelik geloof in die God. wat Homself misterievol in Jesus Christus openbaar, onmoontlik en laat die mens tragies in die steek in sy nood en soeke na sin.

6 Die meeste van due filosowe en denkers van die Verligting was nic ongelowig nie Hulle uitgangspunte het egter 'n paradigma geskep waann daar al hoe minder plek vir God "beskikbaar" geword het soos wat die denksistecm tot sy konsckwensies ontwikkel het 


\subsection{Skeiding tussen feite en waarde}

Die twee bene van die Modemisme het drie verdere gevolge. Die klem op die rasionele het daartoe gelei dat daar onderskeid gemaak is tussen feit en waarde. Geloof, waardes, etiek, reg en verkeerd is beskou as subjektiewe oordele, nie feite nie. Op feite kon 'n mens peil trek, op waardes nie. Die kerk het immers ook nie uit een mond oor waardes gepraat nie. Waardes kom telkens in die pad van die voortgang van die wetenskap. Die sekondêr-stel van waardes kom ook in die ekonomie voor. In 'n hoogs kompeterende ekonomiese stelsel het die winsmotief soveel mag ontwikkel dat waardes en norme nie daarteen opweeg nie (vergelyk byvoorbeeld die pornografiebedryf). Wetenskap, tegnologie en ekonomie het geen gewete nie. Dinge soos die slawehandel, die moord op ses miljoen Jode, die gooi van atoombomme, die vernietiging van die ekologie, beheer oor die menslike lewe, ensovoorts, staan in die teken hiervan. Die rasionele, of te wel intellektuele dimensie van die mens se bestaan, het die affektiewe en konatiewe in in baie groot mate oorheers.

Die implikasie hiervan is die verlies aan waardes en die geweldige spanning rondom etiese kwessies wat vandag in die wêreld bestaan. Daar moet êrens 'n streep getrek word in terme van die vernietiging van die ekologie en in terme van sedelike en morele kwessies. Wie bepaal die norme? As norme wankel, is korrupsie en individuele behoeftebevrediging (vgl. aborsie) logiese uitvloeisels. Ons ervaar dit tans in SA.

\subsection{Skeiding tussen subjek en objek}

Die subjek-objek-onderskeiding is 'n logiese uitvloeisel uit bogenoemde. Die oomblik wanneer die mens self sentraal staan en probeer om God te wees, objektiveer en gebruik (manipuleer) hy alles om hom. Hierdie ingesteldheid het gelei tot die vernietiging van verhoudings. Alles word gebruiksobjekte. Met die onderwaardering van die emosie en waardes word die kille logika van selfsugtige behoeftes in huwelik, gesin, sosiale samelewing en kultuur 'n wrede tiran. Selfs God en sy Woord word vir menige teoloog 'n objek wat hy vryblywend bestudeer. Hy bestudeer die teks maar laat ter wille van wetenskaplike objektiwiteit nie toe dat die teks met hom praat nie. Hy praat en skryf oor die kerk, maar neem nie deel nie, leef nie mee nie. Hy word 'n outoriteit op etiek, maar kies sy eie waardes. Ironies, die vernietiging van verhoudings veroorsaak dat die individualisme platval en ontaard in massafikasie en konformisme (Wells, 1993:187-216). Verskille word gelykgemaak, almal moet gelyk (= eenders) wees. Die verbruikersmaatskappy se massaproduksie en massamanipulasie (vergelyk die modes) ontneem die moderne mens sy individualiteit (Gunton, 1993:44). Die verhoudingsverval in huwelik, gesin en lussen groepe in die SuidAfrikaanse samelewing is aan ons nie onbekend nie. Geweld en misdaad, vergrype teen jou naaste het deel van 'n Suid-Afrikaanse identiteit geword. 


\subsection{Horisontalisme}

Die verhouding waarin oorsaak en gevolg gesien is, draai $180^{\circ} \mathrm{om}$ : eers was God die oorsaak van alles wat die mens nie kon verklaar mie. Die Middeleeue het met die onderskeiding tussen transendent (genade) en immanent (natuur) gewerk (Rossouw, 1993:895-896). Daarvolgens was die wêreld en die ganse sosiale orde (die immanente, die natuurlike wêreld) ondergeskik aan God, die Transendente en sy orde. As verteenwoordiger van die goddelike orde het die Roomse Kerk mag en invloed gehad. Hulle het gevolglik dié orde verdedig. Die Middeleeuse wêreldbeeld het soos volg daar uitgesien:

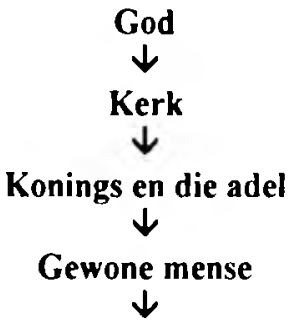

Die natuur, diere, plante en dinge

Die Verligting keer hierdie orde om: die rasionele werk met 'n oorsaakgevolgskema - 'n kousale denkpatroon. Daar is in hierdie denkskema nie ruimte vir geloof en waardes nie want dit kan nie logies-wetenskaplik en empiries bewys word nie; gevolglik word die mens as 't ware afgesny van die Transendente. Tyd en plek, hier en nou, is waarom alles draai. ${ }^{7}$ Hiermee is die tafel gedek vir wanhoop en sinloosheid. Die doel van 'n mens se bestaan, die sin van die lewe, het binne 'n deterministiese kousale denkpatroon geen ruimte nie. Binne so 'n denkraamwerk en kriteria is daar nie plek vir 'n Christelike toekomsverwagting wat op God se Woord en belofte bou nie. Indien die teologie alleen volgens die logika en rede bedryf word, as empiriese feite alleen waarheidskarakter, betroubaarheid het, is daar geen plek vir die misteric nie; openbaring in terme van die nuwe hemel en nuwe aarde maak dan ook geen sin uit nie. Selfs skepping en verlossing word in terme van menslike kategorieè gedink: die ontwikkeling van jou eie potensiaal, self-made mans/vroue wat hul eie tekortkominge oorwin, word oral vir ons voorgehou.

Baie van die tipiese kenmerke van ons samelewing hou hiermee verband. Die feit van ons onvermoe om vrede te vind met die sikliese aard van tyd en die

7 Vergelyk Qucen se licd waar Freddy Mercury (onlangs oorledc aan vigs) met in skrocustem sing: "I want it all, and I want it now". Voor ons dic jeug te veel veruyt, moet ons eers na ons eie gejaag kyk. Praatjies oor die weer was vroeèr tipiese informcle kommunikasic. Tans vertel ons mekaar hoe besig ons is (vgl Banks, 1984). 
onmanipuleerbaarheid van God en sy skepping word benadruk deur, aan die een kant, depressie en selfmoordneigings, tot, aan die ander kant, ons oordrewe klem op gesondheid en die strewe na 'n tipe ewige jeug.

Die ontkieming van hierdie eienskappe van ons tydsgees het die proses van sekularisasie op weg gebring. Die ontluikende wetenskap van sosiologie wat met die reêls van logika werk, empiriese, objektiewe waarnemings maak en induktief verwerk, verklaar dat God en godsdiens gedoem is om van die toneel te verdwyn (Cox, 1965; Milbank, 1990:51-100). Selfs teoloë stem later hiermee saam. ${ }^{8}$ Die eindresultaat van bogenoemde denkraamwerk was 'n sekulêre wêreld, 'n wêreld wat in sy normale gang nie met God kan rekening hou nie, nie kan glo nie, en ook nie waardes kan handhaaf nie.

\section{Die sekulêre wêreld: Modernisme}

Die krag en groei van die Modernisme is gedryf deur die wetenskap en tegniek, die proses van industrialisasie en verstedeliking, die ontstaan van die kapitalistiese stelsel en sy bemarkingsarm in die telekommunikasie (Wells, 1994:7-9). Die denkklimaat waarbinne hierdie dinge gebeur het, bied die sleutel waarmee ons onsself en ons wêreld kan verstaan. In 'n sekere $\sin$ is die Modernisme die produk van die Verligting se uitgangspunte vermenigvuldig met die proses van sekularisasie. Rasmussen (1993:26-27) se definisie van Modernisme is ' $n$ interessante samevatting van die denkraamwerk:

Modernisme is die geloof en belofte dat 'n rasioneel-wetenskaplike program en proses aan die mensdom sekuriteit en beheer oor sy wêreld sal gee. Hierdie denkrigting is verder gebaseer op 'n kapitalistiese/sosialistiese, ekonomiese produksiemasjien; op die veronderstelling dat die volk (the people) uit vrye keuse sy regering en beleid demokraties verkies; dat 'n volkstaat (nation state) die hoogste vorm van politieke soewereiniteit is; dat die volk of burgery die dinamiese spilpunt van groei en ontwikkeling is.

Verstedeliking en industrialisasie het die wêreld onherroeplik verander: skielik was daar nuwe wêrelde, nuwe markte, nuwe behoeftes. Die ekonomie het al hoe meer markgerig/kapitalisties begin raak en die verbruikersmaatskappy het ontwikkel. Die groot multinasionale maatskappye is ongelooflik magtig. Die produksiemaatskappy is soos 'n voortsnellende gedrog wat alles voor hom platvee: dit verorber grondstowwe, skei afval uit en besoedel die ganse wêreld. Die ekologiese balans van die aarde dreig om onherstelbaar versteur te word. Op die menslike maatskappy het dit 'n paradoksale uitwerking: dit skep rykdom en armoede; dit ontwikkel en vernietig; dit lei tot vooruitgang en agteruitgang; tot

8 Vergelyk dic bock van J.A.T Robinson Hones/ to God (1963), waann hy die stelling maak dat God vir die moderne wéreld dood is 
die verlenging van lewe en vernietiging daarvan; tot geboortebeperking en oorbevolking; tot werkskepping en werkloosheid (Winter, 1996:466-475).

\section{Die einde van die Modernisme in sig: Postmodernisme}

Die Modernisme is gedra deur 'n geloof in die mens se potensiaal om goed te wees, evolusionêr te ontwikkel en 'n utopia op hierdie aarde te skep. $\mathrm{Na}$ die vernietigende oorloë wat almal ontgogel het, is 'n wantroue in die ideale van die Modernisme aan die orde van die dag. Die ou waarheid dat die mens in die diepste van sy wese tot niks goeds in staat is nie, word al hoe duideliker besef. Empiriese, historiese feite verifieer dit immers. Soveel dinge wai in die modeme maatskappy skeefloop, het die optimisme van die Verligting ontgogel (Moltmann, 1994:82). Daar is tekortkominge in die denkstruktuur van die Modernisme9 (Wells, 1993, 1994; McGrath, 1996).

Die Eeu van die Verligting was 'n tyd van ongekende ontwikkeling. Daar is met reuse tree gevorder. Deur die foute wat gemaak is, is waardevolle lesse geleer. 'n Nuwe era se verstaanstruktuur moet nou vorm kry. Geloof en waardes sal hierin waarskynlik weer 'n belan-rike rol speel onıdat daar nie meer absolute outoriteit aan rasionalitell w magsmanipulasie verleen gaan word nie. Die postmodernistiese konteks is verskillend en 'n totale herinterpretasie van die werklikheid is in proses.

Paradigmaverskuiwings is prosesmatig. Sekere aspekte soos die ekonomie van die modernistiese sisteem sal waarskynlik 'n lang en uiters ingewikkelde nawerking hê. Oor die aanvanklike kenmerke van die postmodernistiese era ${ }^{10}$, is

9 Vergelyk die Amold Schwartzenegger films: "True lies" en "Junior" Hier sıen 'n mens hoe daar aan 'n normale samelewing gewantrou word Dit is tong-in-dic-kicsvermaak, wanhopige spot. Die wêreld is besig om absurdhede moontlik te maak (Wclls, 1994:46)

10 Postmodernisme veruys na 'n periode na dic Modernisme Dit is interessant dat dit die Protestantse skeptisisme, sy bevraagtekening is, wat die cinde van die Modernisme ingclui het. Die sentrale mites van die Modemisme word bevraagicken: rasionaliteit, humanisme. die gewaande utopie wat sou aanbreek. Die Modernisme het sulke magtige strukture geskep wat utteindelik so 'n manipulerende uitwerkıng gehad het dat die Postmodernısme daarteen rebelleer. Dit wantrou alle "groot skcmas", alle metanarratives, met ander woorde dit breek af of bewerk dekonstruksie: vandaar dic verwerping van rasionaliteit as enigste normatieve kenbron en objektiwitelt as haalbaarheid (Rasmussen, 1993:31; Turnau, 1994:345-377). Dic gevolg is natuurlik 'n groter fragmentasic en nog moer menings plurali me en relativisme is aan die orde van dic nuwe dag David Tracy (1994:108) toon 'n meer optimistiese of reformerende post-alternaticf aan. Hy sî ware Postmodernisme begin by ' $n$ eticse verset toen die waardes van die Modemisme Die Modemisme was 'n indraai. ' $n$ konsentrasie op die selfsugtige self. Die Postmodemisme is egter wesenlik 'n wegdraat, 'n nugkeer op die self en 'n uitreik na die ander, dit wat anders is. Teologies gesproke word God as die "Gans Andere" weer die fokuspunt, die ander mens is my naste, God se openbaring is so totaal anders, nuut, bevrydend (vg] Smit 
daar reeds baie geskryf (vgl. Borgmann, 1992). Die Modernisme is egter nie verby nie. Die bevraagtekening van die rede of rasionaliteit as hoogste norm van die Modernisme lei tot pluralisme en relativisme. Dit beteken dat 'n groot verskeidenheid "gelowe" skielik ontstaan om die geloofwaardigheidsgaping in die grondvooronderstellings van die Modernisme te probeer vul. Die gang van die moderne lewe, die ekonomie en kultuur, bly egter nog modernisties; dit is in ons bloed.

\section{Samevatting}

Ons is aan die einde van 'n era en word gekonfronteer met nuwe, groot uitdagings.

Die Verligtıng het met individualisme en rasionalisme moderne mense in die middelpunt van hul eie bestaan geplaas. As subjek het die eksponente van die Verligting met hul rede, sonder dat nonne hul werklik bind, alles as manipuleerbaar beskou en voorsien dat hul die wêreld 'n beter plek sou maak God is algaande buite rekening gelaat en die kerk het as eens magtige rolspeler na die sfeer van die private lewe begin verdwyn. In plaas van 'n beter wêreld, het die gevaar van bandeloosheid, selfvernietiging, asook ekonomiese en militêre magsmisbruik, die wêreld 'n meer onseker plek vol matelose ellende vir die annes gemaak. Ook Suid-Afrika, met al sy diversiteit, het volledig in hierdie situasie arriveer. 'n Deel van sy mense lewe nog Middeleeus, 'n groter deel is modemisties en 'n groeiende deel is ontgogel en staan besluiteloos of is krities eksperimenterend op soek na sekerheid en rigting.

Die samelewing waarin ons leef, is sekulêr. Die norme wat daar geld, is telkens in botsing met fundamentele Christelike beginsels. Die owerheid het geen verpligting of verbintenis om Christelike beginsels te handhaaf nie As die kerk dus inspraak in die besluitnemingsprosesse van die land wil hê, sal hy binne die sisteemreèls van die huidige bedeling sy getuienis moet laat geld. Dit beteken dat Christene (denominasies) ekumenies sal moet saamwerk en as invloedryke NGO (non governmental orgunisation) hulle oortuigings laat geld.

Die kerk self verkeer in 'n opwindende en uitdagende tyd. Die ankers wat institusioneel-hiërargies met soveel sisteemdwang die status quo as 't ware gevries het, is weens die groot veranderinge in die land losgeruk. Die kerk moet sy identiteit as seël en teken van die Koninkryk in hierdie konteks herontdek. Ons moet onsself leer sien soos ons werklik is voor die aangesig van die lewende God. Verandering begin by bekering. Verandering is ' $n$ omdraai wat God deur

[1995 3-16] oor Bonhocffer as Postmodemis, as iemand wat bereid was on vir die ander sy lewe te $\mathrm{g}(\mathrm{c})$ 
sy Gees laat gebeur sodat sy Seun se bloed ons reinig en ons identiteit herskep. Dit is 'n tyd wat roep om visioenêre leierskap en lewende geloofsgemeenskappe.

\section{Bibliografie}

BABIN, P. 1991. The new era in religious communication. Minneapolis : Fortess Press.

BANKS, R 1984. The tyranny of time Leicester : IVP.

BANKS, R. \& BANKS, J. 1986 . The church comes home A new base for community and mission. Sutherland : Albatross Books.

BORGMANN, A. 1992. Crossing the postmodern divide. Chicago : The University of Chicago Press

BOSCH, D.J. 1991. Transforming mission: Paradigm shifts in theology of mission Maryknoll : Orbis.

BRIERLEY, P. 1989. Vision building: Knowing where you are going London : Hodder \& Stoughton.

BRUEGGEMANN, W. 1993. Texts under negotiation The Bible and postmodern imagination Minneapolis : Fortress.

CARROLL, J.W., DUDLEY, C.S. \& McKINNEY, W. 1986 Handbook for congregational studies Nashville: Abingdon.

COALTER, M.J, MULDER, J.M. \& WEEKS, L B 1992 The re-forming tradition; Presbyterians and mainstream Protestantism. Westminster : John Knox

COX, H. 1965. The secular city: Secularization and urbanization in a theological perspective New York : Macmillan

DEKKER, G. 1992. De stille revolutie: De ontwikkeling van de Gereformeerden Kerken in Nederland tussen 1950-1990. Kampen : Kok

FINKE, R. \& STARK, R. 1992. The churching of America 1776-1990: Winners and losers in our religious economy. New Jersey : Rutgers University Press

GUNTON, C.E. 1993. The One, the three and the many: God, creation and the culture of modernity. New York : Cambridge University Press

HENDRIKS, H J 1995. South African denominational growth and decline 1911-1991 Journal of Theology for Southern Africa, 91:35-58, Jun.

HENDRIKS, H J 1996 Kerkspieel IV en NGK statistiek in die wyer perspektief van die Suid-Afrikaanse bevolkingsensusse 1911-1991 Ned. Geref Teoiogiese Tydskif. 37:138-45, Mrt en 37 479-86, Sept.

McGRATH, A.E. 1996. A passion for truth Leicester : Apollos (IVP)

MEAD, L.B. 1991. The once and future church Reinventing the congregation for a new mission frontier. Washington : Alban Institute

MEAD, L B. 1994 Transforming congregations for the future. New York Alban

MEEKS, W.A. 1983. The first urban Christians The social world of the apostle Paul New Haven : Yale University Press

MILBANK, J 1990 Theology and social theory. Beyond secular reason Oxford Blackwell 
MOLTMANN, J. 1994 Christianity and the third millenium Theology Today, 51(1):75-89, Apr

RASMUSSEN, L.L. 1993. Moral fragments and moral community: A proposal for church in society. Minneapolis : Fortress Press

ROBINSON, J A T. 1963. Honest to God. London : SCM.

ROSSOUW, G.J. 1993 Theology in a post-modem culture Ten challenges Hervormde Teologiese Studies, 49:894-907, Nov.

SMIT, D.[J] 1995 Dieterich Bonhoeffer and 'the other'. Journal of Theology for Southern Africa, 93:3-16, Dec.

TRACY, D. 1994. Theology and the many faces of postmodernity Theology Todary. 51(1): 104-114, Apr.

TUCKER, G.L. 1990. Enhancing church vitality through congregational identity change. (In Coalter, M.J., Mulder, JM. \& Weeks, L B eds. The mainstream Protestant "decline", the Presbyterian pattern. Westminster : John Knox. p 66-85)

TURNAU, T.A. III, 1994. Speaking in a broken tongue Postmodernism, principled pluralism, and the rehabilitation of public moral discourse Westminster Theological Journal. 56(2):345-77, Fall

WELLS, D F 1993. No place for truth: Or whatever happened to evangelical theology? Grand Rapids : Eerdmans

WELLS, DF. 1994 God in the wasteland: The reality of truth in a world of fading dreams. Grand Rapids : Eerdmans

WINTER, G 1996. America in search of its soul Theology Today. 52(4) 466-475, Jan 
